\title{
Review in Different Morphology of Pituitary Gland Using Magnetic Resonances Imaging
}

Shayma Hamed ${ }^{*}$, Ayad CE ${ }^{1}$, Alaa Ibrahim ${ }^{2,4}$, Nisreen Hassan², Amna Mohamed Ahmed ${ }^{2}$, Nmariq Abdbalrhman ${ }^{2}$, Kawthar Moh. Sharif Abdulrhman ${ }^{3}$

${ }^{1}$ Sudan University of Science and Technology, College of Medical Radiology Sciences, Khartoum, Sudan

${ }^{2}$ Department of Radiological Sciences, Al-Ghad International College, Tabouk, KSA

${ }^{3}$ Department of Radiological Sciences, Al-Ghad International College, Riyadh, KSA

${ }^{4}$ University of Medical Sciences and Technology, Khartoum, Sudan

DOI: $\underline{10.36347 / \text { sjams.2020.v08i10.037 }}$

| Received: 11.10 .2020 | Accepted: 25.10.2020 | Published: 29.10.2020

*Corresponding author: Shayma Hamed

Abstract

Original Research Article

Magnetic resonance (MR) occurs in the magnetic system that contains both magnetic moments and angular momentum [1]. Various radiological modalities that had been used to study gland such as computed tomography but MRI has proved to be an accurate diagnostic modality for the assessment of pituitary gland. Normal pituitary gland shows variation in size and shape, transient changes in the shape or signal intensity of the pituitary gland appears at different stages of life [2]. The gland tends to be rounded in shape at birth and becomes more flattened with age. This review study aimed to summarize the author's articles about the shapes of normal pituitary gland when they are using the magnetic resonance imaging as imaging modalities. Authors discussed and illustrated the various shapes of gland are convex, concave most common in females and the flat shape are common in males.

Keywords: Review, Pituitary gland, magnetic resonance imaging.

Copyright $($ C) 2020 The Author(s): This is an open-access article distributed under the terms of the Creative Commons Attribution 4.0 International License (CC BY-NC 4.0) which permits unrestricted use, distribution, and reproduction in any medium for non-commercial use provided the original author and source are credited.

\section{BACKGROUND}

The pituitary gland (hypophysis cerebri) is a reddish grey, ovoid body which lies within the hypophyseal fossa of the sphenoid bone. The gland measures about $12 \mathrm{~mm}$ in transverse and $8 \mathrm{~mm}$ in antero-posterior diameter and weighs about $500 \mathrm{mg}$. It is covered superiorly by diaphragma sellae, which is pierced centrally by an aperture for the infundibulum. Structurally the gland is divided into a larger anterior region (adenohypophysis) and smaller posterior region (neurohypophysis). They differ in structure, development, and their vascular and neural supplies. The gland produces several hormones that regulate growth, metabolism and reproduction. Deviations from the normal functions of the gland certainly derange the harmony of life [3]. Pituitary gland morphology is altered in many situations like Prolactinomas (60\%)[4], somatotrophic adenoma(30\%) [5] and pituitary adenomas which accounts for $10-15 \%$ of all diagnosed intracranial neoplasms[6].

Variation in the pituitary gland shape in sagittal section:

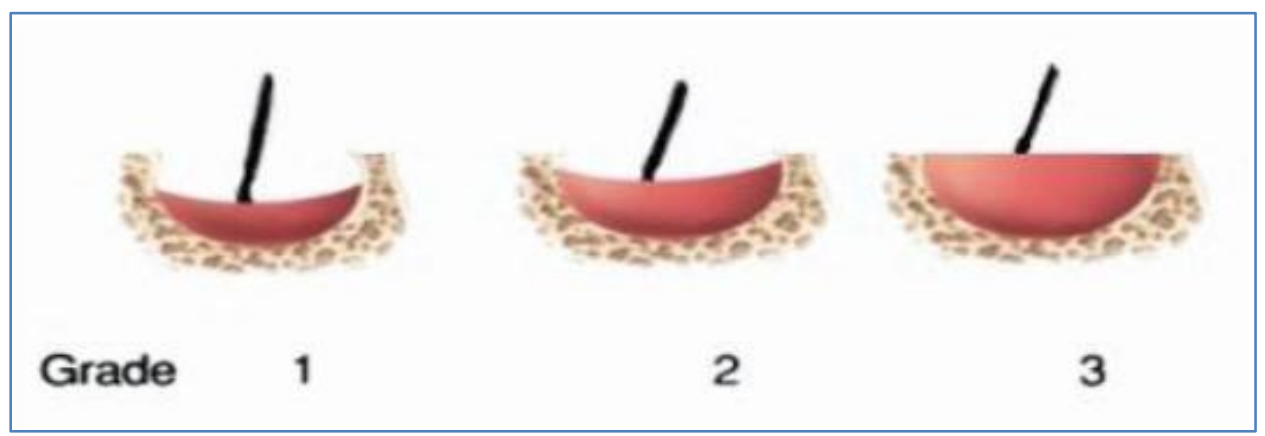

Fig-1: Scheme grade score for the shape evaluated in sagittal views Grade 1 (G1) call "Concave", Grade 2 (G2) call "Concave" (different than G1, less than center of gland $2 \mathrm{~mm}$.), Grade 3 (G3) call "Flat" [7] 

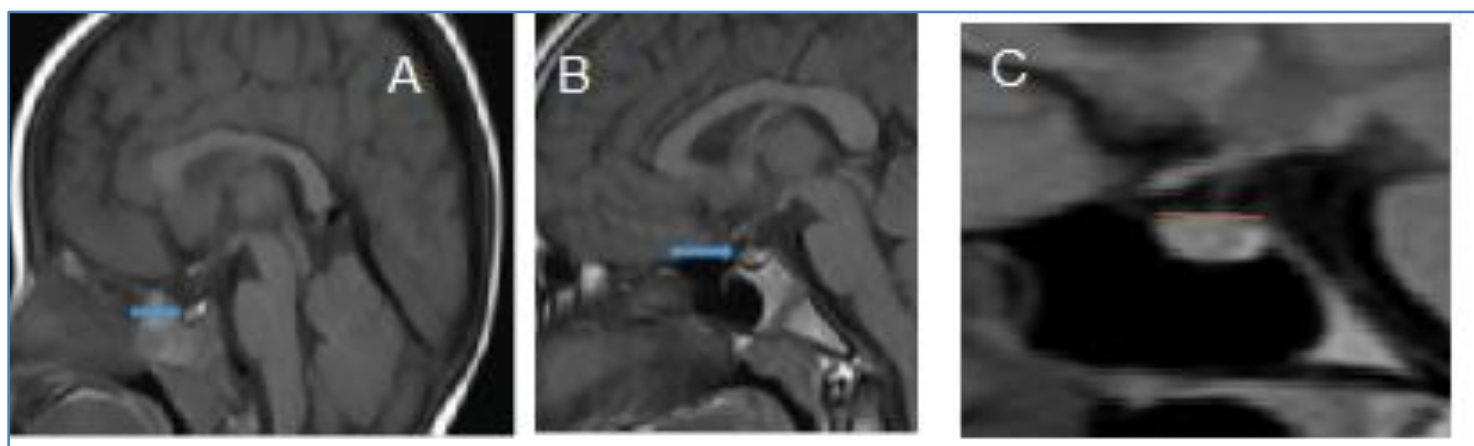

Fig-2: Sagittal T1 weighted MRI of Pituitary gland shapes demonstrated by arrows A. concave B. convex C .flat [8]

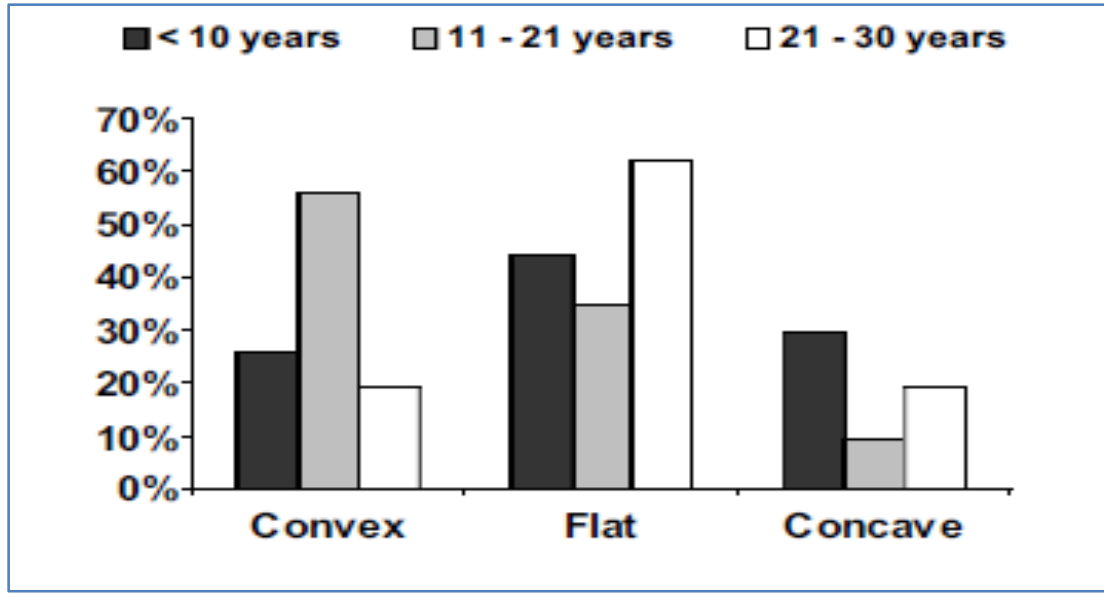

Fig-3: Shape of the superior surface of the pituitary gland in Females [8]

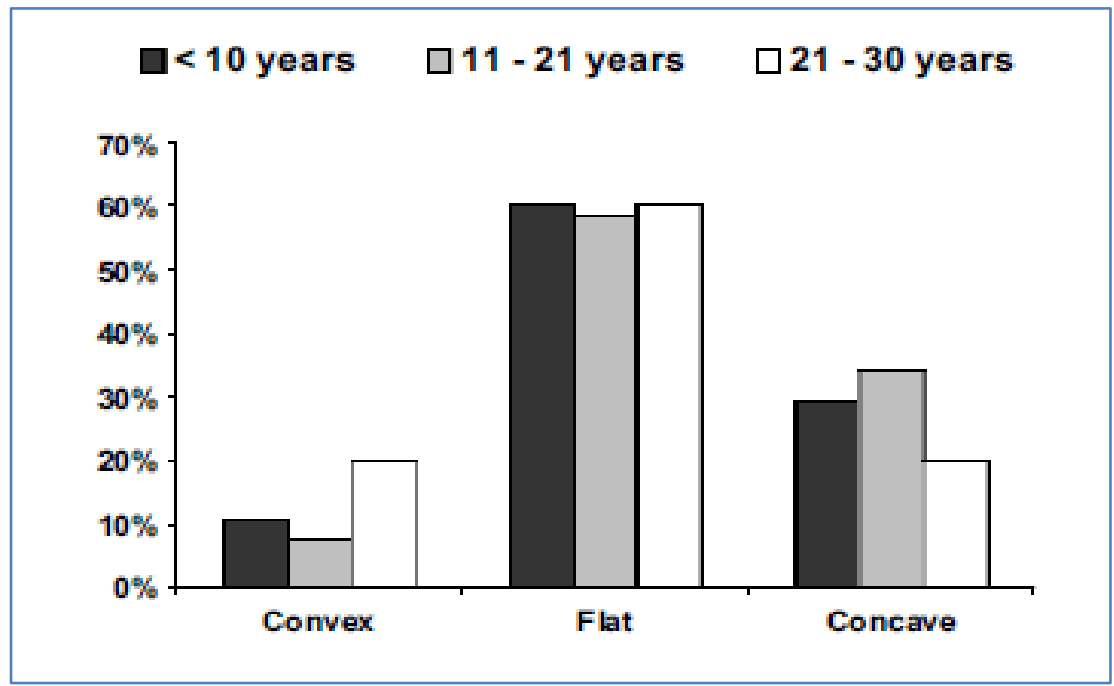

Fig-4: Shape of the superior surface of the pituitary gland in Males [8]

\section{OBJECTIVES}

This review study aimed to summarize the author's articles about the shapes of normal pituitary gland when they are using the magnetic resonance imaging as imaging modalities. Authors discussed and illustrated the various shapes of gland such as convex, concave and flat most common seen in the mid sagittal and coronal images.

\section{Materials ANd Methods}

6 articles in different peer reviewed journals were selected by authors and then analyzed and summarized in table1 to compare between different findings. The manuscripts were selected according to the main objective of this review article, any manuscript that were not found as full-text were excluded from this review article. The article was accessed provided by open access internet using Google scholar search. 
Table-1: Main results of research used in this review article.

\begin{tabular}{|c|c|c|c|}
\hline Title & Authors & Source & Main finding of shapes \\
\hline $\begin{array}{l}\text { MRI Evaluation of Size } \\
\text { and Shape } \\
\text { of Normal Pituitary Gland: } \\
\text { Age } \\
\text { and Sex Related Changes }\end{array}$ & $\begin{array}{l}\text { Yadav,P.Singhal, } \\
\text { S.,Chauhan,S.and Harit, } \\
\text { S., 2017. }\end{array}$ & $\begin{array}{l}\text { Journal of Clinical and } \\
\text { Diagnostic Research. } \\
2017 \text { Dec, Vol-11(12): } \\
\text { TC01-TC04 }\end{array}$ & $\begin{array}{l}\text { The most common shape was } \\
\text { flat which was seen in } 46 \% \text { of } \\
\text { people followed by convex in } \\
31.2 \% \text { and concave shape in } \\
22.8 \% \text { [9]. }\end{array}$ \\
\hline $\begin{array}{l}\text { Size,shape,and appearance } \\
\text { of the normal female } \\
\text { pituitary } \\
\text { gland }\end{array}$ & $\begin{array}{l}\text { Wolpert, S.M., Molitch, } \\
\text { M.E., Goldman, J.A. and } \\
\text { Wood, J.B., } 1984 .\end{array}$ & $\begin{array}{l}\text { American journal of } \\
\text { Roentgenology, 143(2), } \\
\text { pp.377-381. }\end{array}$ & $\begin{array}{l}\text { The superior margins of the } \\
\text { glands were convex in 19; The } \\
\text { superior margins of the glands } \\
\text { were concave in } 33 \text { patients [10]. }\end{array}$ \\
\hline $\begin{array}{l}\text { Age and Gender Related } \\
\text { Variations of Pituitary } \\
\text { Gland } \\
\text { Size of Healthy Nepalese } \\
\text { People Using Magnetic } \\
\text { Resonance Imaging }\end{array}$ & $\begin{array}{l}\text { Lamichhane, T.R., } \\
\text { Pangeni, S., Paudel, S. } \\
\text { and Lamichhane, } \\
\text { H.P2015. }\end{array}$ & $\begin{array}{l}\text { American Journal of } \\
\text { Biomedical } \\
\text { Engineering, 5(4), } \\
\text { pp.130-135 }\end{array}$ & $\begin{array}{l}\text { The shape of the superior surface } \\
\text { of the gland (SS) was convex } \\
\text { upper border was more common } \\
\text { in females the flat upper surface } \\
\text { was more common [11]. }\end{array}$ \\
\hline $\begin{array}{l}\text { Magnetic Resonance } \\
\text { Imaging Determination } \\
\text { of Normal Pituitary Gland } \\
\text { Dimensions in } \\
\text { Zaria, Northwest Nigerian } \\
\text { Population }\end{array}$ & $\begin{array}{l}\text { Ibinaiye, P.O., Olarinoye- } \\
\text { Akorede, S., Kajogbola, } \\
\text { O. and Bakari, A.G.,2015. }\end{array}$ & $\begin{array}{l}\text { Journal of Clinical } \\
\text { Imaging Science | Vol. } \\
5 \text { | Issue 2 | Apr-Jun } \\
2015\end{array}$ & $\begin{array}{l}\text { This study not focused in shape } \\
\text { and reported that there no } \\
\text { statistically significant } \\
\text { difference between pituitary } \\
\text { height and pituitary volume in } \\
\text { both sexes [12]. }\end{array}$ \\
\hline $\begin{array}{l}\text { Size and Shape of the } \\
\text { Pituitary Glandwith MR } \\
\text { Imaging from Newborn to } \\
30 \text { Years: A Study at } \\
\text { Siriraj Hospital }\end{array}$ & $\begin{array}{l}\text { Keanninsiri, C., Cheiwvit, } \\
\text { P., Tritrakarn, S., } \\
\text { Thepamongkhol, K. and } \\
\text { Santiprabhop, J., } 2012 \text {. }\end{array}$ & $\begin{array}{l}\text { Journal of Evolution of } \\
\text { Medical and Dental } \\
\text { Sciences, 3(18), } \\
\text { pp.4934-4940 }\end{array}$ & $\begin{array}{l}\text { The most of frequency grade of } \\
\text { shape, in sagittal views were } \\
\text { type of "flat" in male all groups, } \\
\text { in female groups higher } \\
\text { frequency type of "convex" } \\
\text { same as coronal views [7]. }\end{array}$ \\
\hline $\begin{array}{l}\text { Pituitary Height } \\
\text { onMagnetic Resonance } \\
\text { Imaging Observation of } \\
\text { Age and Sex } \\
\text { Related Changes }\end{array}$ & $\begin{array}{l}\text { Ikram, M.F., Sajjad, Z., } \\
\text { Shokh, I. and Omair, A., } \\
2008 .\end{array}$ & $\begin{array}{l}\text { JPMA. The Journal of } \\
\text { the Pakistan Medical } \\
\text { Association, 58(5), } \\
\text { p.261. }\end{array}$ & $\begin{array}{l}\text { Convex upper border was } \\
\text { more common in females In } \\
\text { males, frequency of flat upper } \\
\text { surface was more common [13]. }\end{array}$ \\
\hline
\end{tabular}

\section{DISCUSSION}

This manuscript considered attempt to enhance the role of MR imaging in assessment of pituitary gland shape and elevating accurate method for the measurement in the mid sagittal. Authors found that the mid sagittal and coronal T1-weighted images are the most practical method to evaluate the gland shape.

Table 1 shows the shape different in pituitary gland with convex shape most common in female and flat shape in male. Some authors correlated the different in shape of the gland with gender and age groups Wolpert, S.M et al. 1984 found that concave shape more often in the older than in the younger women vice versa to convex shape more common in younger women[10]. In agreement with Lamichhane, T.R et al. found a higher frequency of convex upper border in female than in male [11]. This difference was much higher in 10-20 year age group. In females, frequency of convex upper margin peaked in 10-20 years age group and in males, it was found in 20-30 year age group. There was no gender difference in the shape of the upper border in 20-30 year age group, though the frequency of flat upper margin was higher in this age group. Sanjay, S.C et al. also noted that the gland was more convex/globular in the younger age group (20-29) but as advanced the superior surface became more concave [14].

Flat superior surface was seen predominantly in the age group (30-39). Consistency with Ikram, M.F et al. Convex upper border was more common in females in $<20$ years cases. In males, frequency of flat upper surface was more common. Also found a higher frequency of convex upper border in female (38\%) than in male $(12 \%)$ [13].

This difference was much higher in 11-20 year age group $($ male $=7 \%$, female $=56 \%$ ). In females, frequency of convex upper margin peaked in 16-20 years age group (71\%) and in males, it was found in 2025 year age group (30\%). There was no gender difference in the shape of the upper border in $21-30$ year age group, though the frequency of flat upper margin was higher in this age group.

Keanninsiri, C et al. The most of frequency grade of shape, in sagittal views were type of "flat" in male all groups (1-3) 58\%, 62\% and $65 \%$ but no 
significant $(p=0.724)$ and $48 \%, 58 \%$ in female groups except in female groups 2(11-20 years) higher frequency type of "convex" equal to $54 \%$ include statistic significant $(\mathrm{p}=0.001)$. In coronal views most of frequency grade of shape type of "flat" was shown in $64 \% 64 \%$ and $67 \%$ in male and no significant $(\mathrm{p}=$ $0.746), 44 \% 38 \%$ and $60 \%$ in female but in groups 2(11-20 years) tend type to "convex" include this groups was statistic significant $(\mathrm{p}=0.016)$ [7].

\section{CONCLUSION}

This review article considers as reference values for the shape of pituitary gland, the midsagittal MR sections reflect the gland morphology more accurately. Authors discussed and illustrated the various shapes of gland are convex, concave most common in females and the flat shape are common in males.

\section{REFERENCES}

1. Brown RW, Cheng YC, Haacke EM, and Thompson MR, Venkatesan R. Magnetic resonance imaging: physical principles and sequence design. John Wiley \& Sons; 2014 Jun 23.

2. Dietrich RB, Lis LE, Greensite FS, Pitt D. Normal MR appearance of the pituitary gland in the first 2 years of life. American journal of neuroradiology. 1995 Aug 1;16(7):1413-9.

3. Crossman AR. ed. Neuroanatomy. In: Standring S, Ellis H, Heally JC, Johnson D, Williams A, Collins P. eds. Gray's Anatomy: The anatomical basis of clinical practice. 39th ed. Edinburgh: Elsevier Churchill Livingstone. 2005. 380-83.

4. Aron DC, Findling JW, Tyrrell JB. eds. Hypothalamus and pituitary gland. In: Greenspan FS, Gardner DG. Eds. Basic and clinical endocrinology. 7th Ed. New York: McGraw Hill. 2004.106-63.

5. Maitra A, Abbas KA. Eds. Diseases of the endocrine system. In: Kumar V, Abbas AK, Fausto $\mathrm{N}$. eds. Robbins and Cotran pathologic basis of disease. 7th ed. New Delhi: Saunders. 2004. 115664.

6. Hemminki K, Forsti A and Ji j. Incidence and Familial risks in pituitary adenoma and associated tumors. Endocrine related cancer. 2007; 14: 10309.

7. Keanninsiri C, Cheiwvit $\mathrm{P}$, Tritrakarn S, Thepamongkhol K, Santiprabhop J. Size and shape of the pituitary gland with MR imaging from newborn to 30 years: a study at siriraj hospital.

8. Yadav P, Singhal S, Chauhan S, Harit S. MRI evaluation of size and shape of normal pituitary gland: age and sex related changes. J Clin Diagn Res. 2017 Dec 1;11(12):TC01-4.

9. Yadav P, Singhal S, Chauhan S, Harit S. MRI evaluation of size and shape of normal pituitary gland: age and sex related changes. J Clin Diagn Res. 2017 Dec 1;11(12):TC01-4.

10. Wolpert SM, Molitch ME, Goldman JA, Wood JB. Size, shape, and appearance of the normal female pituitary gland. American journal of roentgenology. 1984 Aug 1;143(2):377-81.

11. Lamichhane TR, Pangeni S, Paudel S, Lamichhane HP. Age and gender related variations of pituitary gland size of healthy Nepalese people using magnetic resonance imaging. American Journal of Biomedical Engineering. 2015;5(4):130-5.

12. Ibinaiye PO, Olarinoye-Akorede S, Kajogbola O, Bakari AG. Magnetic resonance imaging determination of normal pituitary gland dimensions in Zaria, Northwest Nigerian population. Journal of clinical imaging science. 2015;5.

13. Ikram MF, Sajjad Z, Shokh I, Omair A. Pituitary height on magnetic resonance imaging observation of age and sex related changes. JPMA. The Journal of the Pakistan Medical Association. 2008 May;58(5):261.

14. Sanjay SC, Subbaramaiah M, Jagannatha SR. Variation in size and shape of a normal adult female pituitary gland: A radiological study. Journal of Evolution of Medical and Dental Sciences. 2014 May 5;3(18):4934-40. 